\title{
Teor de óleo e estabilidade fenotípica para rendimento de grãos em cultivares de amendoim
}

\section{Oil content and phenotypic stability for grain yield in peanut cultivars}

\author{
Vânia MODA-CIRINO ${ }^{2}$; Gidiane Prado RIBEIRO ${ }^{1 ; 3}$; Juliana Sawada BURATTO ${ }^{4}$; \\ Samuel Nelson Melegari de SOUZA ${ }^{5}$; Nelson da Silva FONSECA JÚNIOR ${ }^{6}$ \\ ${ }^{1}$ Parte da dissertação de mestrado do segundo autor \\ ${ }^{2} \mathrm{Dr}^{\mathrm{a}}$. em Genética e Melhoramento de Plantas, Eng ${ }^{\mathrm{a}}$. Agrônoma, Instituto Agronômico do Paraná, vamoci@iapar.br \\ ${ }^{3}$ Eng $^{\mathrm{a}}$. Agrônoma, Universidade Estadual do Oeste do Paraná, gidiane.prado@hotmail.com \\ ${ }^{4}$ Autor para correspondência, Dr ${ }^{\mathrm{a}}$ em Genética e Melhoramento de Plantas, Enga ${ }^{\mathrm{a}}$. Agrônoma, Instituto Agronômico do \\ Paraná, Área de melhoramento e genética vegetal, Rod. Celso Garcia Cid, km 375, CEP: 86047-902, Fone: (43)3376- \\ 2326, jsburatto@iapar.com \\ ${ }^{5}$ Dr., Eng Agrônomo, Universidade Estadual do Oeste do Paraná, ssouza@unioeste.br \\ ${ }^{6}$ Dr. em Genética e Melhoramento de Plantas, Eng. Agrônomo, Instituto Agronômico do Paraná, nsfjr@iapar.br
}

Recebido em: 29-10-2014; Aceito em: 23-04-2015

\begin{abstract}
This study aimed to evaluate the oil content and estimate the phenotypic stability and adaptability parameters for grain yield in twelve peanut cultivars. The experiment was carried out in 21 different localities in Paraná State, during the dry and rainy seasons of the agricultural year 2010-2011, 2011-2012 and 2012-2013. The experimental design was a randomized block with four replications and plots consisting of four rows of $4 \mathrm{~m}$ with a population of 16 plants per meter. After maturation, the plots were harvested and grain yield was converted to $\mathrm{kg} \mathrm{ha}^{-1}$ and corrected to $10 \%$ moisture. The oil content (\%) was measured by the ether extract method. Significant effects for cultivars, environments (combination of years, seasons and locations) and $\mathrm{G} \times \mathrm{E}$ interaction was detected for grain yield and oil content in the peanut seeds. The cultivars BRS 151-L7, IAC Tatuí, BRS Havana, IAC Poitara, IAC Oirã and IAC Tupã showed the highest oil content in the grains. Stability and adaptability was estimated for the characteristic grain yield. The cultivars Runner IAC 886 and IAC Caiapó showed specific adaptation to adverse environments, while IAPAR 25 Tição and IAC Tupã to showed specific adaptation to favorable environments. IAC Tatu ST was more stable and Tégua was less stable.
\end{abstract}

Additional keywords: Adaptability; Arachis hypogaea L.; peanut improvement.

\begin{abstract}
Resumo
Este trabalho teve como objetivo avaliar o teor de óleo e estimar os parâmetros de estabilidade e adaptabilidade fenotípica para rendimento de grãos em doze cultivares de amendoim. O ensaio foi conduzido em 21 ambientes distintos no Estado do Paraná, durante as safras das águas e seca, nos anos agrícolas de 2010-2011, 2011-2012 e 2012-2013. O delineamento experimental utilizado foi o de blocos ao acaso, com quatro repetições, e parcelas constituídas de quatro linhas de $4 \mathrm{~m}$, com uma população de 16 plantas por metro. Após a maturação, as parcelas foram colhidas, e o rendimento de grãos obtido foi transformado para $\mathrm{kg} \mathrm{ha}^{-1}$ e corrigidos para $10 \%$ de umidade. O teor de óleo (\%) foi quantificado por extrato etéreo. Para rendimento de grãos e teor de óleo nas sementes de amendoim, foi detectado efeito significativo para cultivares, ambientes (combinação de anos, safras e locais) e para a interação $G \times A$. As cultivares BRS 151-L7, IAC Tatuí, BRS Havana, IAC Poitara, IAC Oirã e IAC Tupã apresentaram os maiores teores médios de óleo nos grãos. A estabilidade e a adaptabilidade foram estimadas para característica rendimento de grãos. As cultivares Runner IAC 886 e IAC Caiapó apresentaram adaptação específica a ambientes desfavoráveis, enquanto IAPAR 25 Tição e IAC Tupã, aos ambientes favoráveis. Em termos de estabilidade, IAC Tatu ST foi a mais previsível, e Tégua, menos estável.
\end{abstract}

Palavras-chave adicionais: Adaptabilidade; Arachis hypogaea L.; melhoramento de amendoim.

\section{Introduction}

Peanut (Arachis hypogaea L.) is grown in Brazil mainly to meet the food industry. The peanut seeds have high oil content, which makes this legume a promising feedstock for biodiesel production (Campos-Mondragon et al., 2009; Santos et al.,
$2012 b)$. Processing of peanut generates numerous by-products that have various applications in the food and feed industry (Zhao et al., 2012).

According to data from FAO (2013), in 2012, world production was approximately 41 million tons. Peanut is produced by many countries, as it adapts to almost all kinds of weather, and the main produc- 
ing countries were China, India, Nigeria and the United States; Brazil occupied the 18th position in the world ranking. In Brazil, peanuts are grown in almost all states and the national production of the 2012-2013 harvest was 330 thousand tons, with a $12 \%$ increase compared to the 2011-2012 harvest in a cultivated area of 100.9 hectares. The State of São Paulo stands out as the largest national peanut producer (CONAB, 2013), where cultivation occurs mainly in areas aimed at reform of sugarcane fields and pastures (Crusciol \& Soratto, 2007).

In the State of Paraná, peanut is grown as a subsistence crop and much of the production comes from small farms. Good soil and climate conditions allow the cultivation in two seasons, during the rainy season, where sowing takes place from September to November, and the dry season, from December to January. In the harvest of 2011-2012, the production was 9,697 tons in an area of 3,743 hectares with an average yield of $2,591 \mathrm{~kg} \mathrm{ha}^{-1}$ (SEAB, 2013).

Peanuts are grown in different seasons and edaphoclimatic conditions in Brazil. This great variety of environments contributes to the occurrence of genotype $x$ environment interaction ( $G \times E)$, ie, the change in relative performance of genotypes due to environmental differences (Murakami \& Cruz, 2004; Oliveira et al., 2006a). For the purpose of $G \times E$ interaction to be minimized or capitalized it is necessary to conduct experiments in the largest possible number of locations and years (Silva \& Duarte, 2006).

When the $G \times E$ interaction is significant it is necessary to evaluate the behavior of genotypes within each environment, this information may be obtained through analyzes of adaptability and stability. These analyzes enable a more accurate indication for recommendation of cultivars, for providing a detailed study about their behavior predictability and adaptability to specific or wide environmental conditions (favorable and unfavorable). Therefore, cultivars recommendation based on stability in various environments, and not in one in specific, is a strategy to reduce the effect of $G \times E$ interaction (Eberhart \& Russell, 1966).

This study aimed to quantify the oil content in the grains and evaluate the adaptability and phenotypic stability for grain yield of twelve peanut cultivars grains in the State of Paraná, to identify cultivars with high yield potential and oil contents adapted to the soil and weather conditions of the location.

\section{Material and methods}

The experiment was established in 21 environments composed by the unbalanced combination of two seasons, three years and five locations in the State of Paraná. The tests were conducted during the rainy season in the agricultural year 2010-2011, 2011-2012 and 2012-2013 and in the dry season in the agricultural year 2011 and 2012. During the rainy season of 2010-2011, the test was established in the municipalities of Irati, Santa Tereza do Oeste, Londrina, Paranavaí and Xambrê. In the rainy season of 2011-2012 it was held in Irati, Londrina, Paranavaí and Xambrê, and in the rainy season of 2012-2013, in Londrina, Paranavaí and Xambrê. In the dry season of 2011 and 2012 the trial was conducted in Irati, Londrina, Santa Tereza do Oeste and Xambrê, and Paranavaí only for the harvest of 2011. Information on the altitude, latitude and longitude of the evaluation locations are shown in Table 1.

Table 1 - Altitude, latitude and longitude of the locations of the experiments of rainy season 2010-2011, 2011-2012 and 2012-2013 and the dry season of 2011 and 2012.

\begin{tabular}{|c|c|c|c|}
\hline Location & $\begin{array}{l}\text { Altitude } \\
---(m)--\end{array}$ & Latitude & Longitude \\
\hline Irati & 836 & $25^{\circ} 28^{\prime}$ South & $50^{\circ} 39^{\prime}$ West \\
\hline Londrina & 550 & $23^{\circ} 17^{\prime}$ South & $51^{\circ} 10^{\prime}$ West \\
\hline Paranavaí & 446 & $23^{\circ} 04^{\prime}$ South & $52^{\circ} 27^{\prime}$ West \\
\hline $\begin{array}{l}\text { Santa Tereza do Oeste } \\
\text { Xambrê }\end{array}$ & $\begin{array}{l}747 \\
374\end{array}$ & $\begin{array}{l}25^{\circ} 03^{\prime} \text { South } \\
23^{\circ} 43^{\prime} \text { South }\end{array}$ & $\begin{array}{l}53^{\circ} 37^{\prime} \text { West } \\
53^{\circ} 29^{\prime} \text { West }\end{array}$ \\
\hline
\end{tabular}

The basic fertilization was done in accordance with chemical analysis of soil, and the control of pests and weeds according to the technical recommendations for culture. The experimental design was a randomized block design with four replications and plots consisting of four rows of $4 \mathrm{~m}$, $0.6 \mathrm{~m}$ spaced, with seeding density of 16 viable seeds per meter, considering as useful portion the two central lines. The treatments were composed by 12 peanut cultivars: IAC Tatu ST, Runner IAC 886, Tégua, IAC Poetara, IAC Tatuí, IAC Tupã, IAC Oira, IAC Caiapó, BRS 151-L7, BRS Havana, BR01 and IAPAR 25 Tição. The cultivars IAC Tatu ST and
Runner IAC 886 were used as control cultivars.

For the determination of the yield, the plants of the two central rows were harvested. After the tracking and cleaning of the material, with the separation of impurities (leaves, branches and clods), the pods were threshed and the grains were weighed. The yield of peanut kernels per plot was transformed into $\mathrm{kg} \mathrm{ha}^{-1}$ and corrected to $10 \%$ moisture. For analysis of oil content (\%) on dry basis, it was taken from each plot a sample of $100 \mathrm{~g}$ of peanut grains. The methodology for determination was by ether extract (AOAC, 1990).

From the data obtained for grain yield and 
oil content, the individual variance analysis for each environment proceeded, according to the model:

$$
Y_{i j}=\mu+g_{i}+b_{j}+\varepsilon_{i j}
$$

On which: $Y_{i j}=$ observation of genotype $\mathrm{i}$ in block j; $\mu$ = mean; $g_{i}=$ effect of genotype; I = genotype $(1,2,3, \ldots 12) ; b_{j}=$ effect of the block; $j=$ replicates $(1$, 2, 3 and 4$) ; \varepsilon_{i j}=$ deviation of observation (j) in genotype (i). To perform the analysis of variance in all the experiments, it was carried out the homogeneity of variance test, using the ratio between the largest and smallest variance of experimental error, accepting the ratio 7:1, according to Banzatto \& Kronka (2006). Being tested the homogeneity of variance, it was performed the joint analysis of the test, for both characteristics, using the following statistical-genetic model:

$Y_{i j k}=\mu+G_{i}+A_{j}+G A_{i j}+B / A_{j k}+\varepsilon_{i j k}$

On which: $Y_{i j k}=$ observation of genotype $\mathrm{i}$ in environment $\mathrm{j}$ in block $\mathrm{k} ; \mu=$ general mean; $G_{i}=$ effect of $i^{\text {th }}$ genotype $(i=1,2 \ldots 12) ; A_{j}=$ effect of $j^{\text {th }}$ environment $(\mathrm{j}=1,2 \ldots 18) ; G A_{i j}=$ effect of the interaction between $i^{\text {th }}$ genotype and $j^{\text {th }}$ environment; $B / A_{j k}=$ effect of $\mathrm{k}^{\text {th }}$ block in jth environment $(\mathrm{k}=1$, $2 . .4) ; \varepsilon_{i j k}=$ random error. For the joint variance analysis, the effects of genotype and environment were considered as fixed. After the joint analysis of data related to grain yield, it was estimated phenotypic stability, with the method proposed by Eberhart \& Russell (1966), adopting the following linear regression model (Cruz \& Regazzi, 1997):

$$
Y_{i j}=\beta_{o i}+\beta_{1 i} I_{j}+\delta_{i j}+\varepsilon_{i j}
$$

On which: $Y_{i j}=$ mean response the $\mathrm{i}^{\text {th }}$ genotype at the $\mathrm{j}^{\text {th }}$ environment $\mathrm{j} ; \beta_{o i}=$ mean of the $\mathrm{i}^{\text {th }}$ genotype at the $\mathrm{j}^{\text {th }}$ environmental; $\beta_{1 i}=$ linear regression coefficient, which measures the response of the ith genotype to the variation of the environment; $I_{j}=$ environmental index coded $\left(\sum_{j} I_{j}=0\right) ; \delta_{i j}=$ deviation of regression; $\varepsilon_{i j}=$ experimental error. The significance of the regression coefficient $\left(\beta_{1 i}=1\right)$ was evaluated by $\mathrm{t}$ test, and the significance of the regression deviations $\left(\sigma_{d i}^{2}=0\right)$ by the $\mathrm{F}$ test at $5 \%$ and $1 \%$ probability. The treatment means were grouped by the method of Scott \& Knott at $5 \%$ and $1 \%$ probability. Statistical analyzes were performed with the help of the Genes software (Cruz, 2006).

\section{Results and discussions}

The individual analyzes of variance were performed for each of the 21 environments. However, it was necessary to discard three environments because of unfavorable weather conditions that have compromised the development of culture, affecting grain yield and raising the experimental error. Deleted environments were: Londrina, dry season 2011-2012; Santa Tereza do Oeste, rainy season 2011-2012; and Londrina, dry season 2012-2013. For grain yield evaluated in peanut cultivars, there was a significant effect of $5 \%$ and $1 \%$ probability for cultivars in 14 of 18 evaluated environments (Table 2). These results indicate that the cultivars showed phenotypic variation for grain yield.

Table 2 - Indivudual variance analysis for grain yield $\left(\mathrm{kg} \mathrm{ha}^{-1}\right)$ in peanut cultivars evaluated in Irati, Londrina, Paranavaí, Santa Tereza do Oeste (S. T. Oeste) and Xambrê in the rainy season of 2010-2011, 2011-2012

\begin{tabular}{|c|c|c|c|c|c|c|c|}
\hline \multirow{2}{*}{ Environment } & \multicolumn{3}{|c|}{ Test } & \multicolumn{3}{|c|}{ Mean Square } & \multirow{2}{*}{$\begin{array}{l}{ }^{3} \mathrm{CV} \\
(\%)\end{array}$} \\
\hline & Season & Agricultural year & Location & Block & ${ }^{2}$ Cultivar & Residue & \\
\hline 1 & \multirow{5}{*}{ Rainy } & \multirow{5}{*}{$2010-2011$} & Irati & 128,442 & 629,139 ** & 112,951 & 21.3 \\
\hline 2 & & & Londrina & 1801,996 & $232,845^{\text {ns }}$ & 169,960 & 15.2 \\
\hline 3 & & & Paranavaí & 274,702 & 825,594 ** & 45,994 & 9.0 \\
\hline 4 & & & S. T. Oeste & 426,472 & $1,205,392$ ** & 123,377 & 13.8 \\
\hline 5 & & & Xambrê & 588,503 & $95,317^{\text {ns }}$ & 194,524 & 13.9 \\
\hline 6 & \multirow{4}{*}{ Rainy } & \multirow{4}{*}{ 2011-2012 } & Irati & 270,516 & 301,056 ** & 65,590 & 20.7 \\
\hline 7 & & & Londrina & 122,560 & $1,463,353$ ** & 86,743 & 12.2 \\
\hline 8 & & & Paranavaí & 364,934 & 230,141 ** & 58,264 & 25.0 \\
\hline 9 & & & Xambrê & 46,501 & 680,760 ** & 32,111 & 22.1 \\
\hline 10 & \multirow{3}{*}{ Rainy } & \multirow{3}{*}{$2012-2013$} & Londrina & 55,893 & $216,847^{\text {ns }}$ & 157,136 & 17.4 \\
\hline 11 & & & Paranavaí & 233,085 & $462,317^{* *}$ & 89,596 & 13.3 \\
\hline 12 & & & Xambrê & 419,655 & 603,466 ** & 79,195 & 18.8 \\
\hline 13 & \multirow{4}{*}{ Dry } & \multirow{4}{*}{$2011-2012$} & Irati & 803,528 & $811,661^{\star \star}$ & 104,731 & 22.9 \\
\hline 14 & & & Paranavaí & 33,681 & 119,952 * & 49,567 & 14.2 \\
\hline 15 & & & S. T. Oeste & 281,551 & 249,858 * & 115,142 & 18.2 \\
\hline 16 & & & Xambrê & 45,977 & $39,036^{\mathrm{ns}}$ & 34,853 & 16.0 \\
\hline 17 & \multirow{2}{*}{ Dry } & \multirow{2}{*}{ 2012-2013 } & S.T. Oeste & 73,412 & $419,100^{* *}$ & 60,302 & 18.4 \\
\hline 18 & & & Xambrê & 73,263 & 107,259 ** & 32,486 & 23.6 \\
\hline
\end{tabular}
and 2012-2013 and in the dry season of 2011 and 2012.

'Degrees of freedom: 3 (block); 11 (cultivar); 33 (residue). ${ }^{2} \mathrm{~F}$ test: ${ }^{* *} ;{ }^{*}$ significative to $1 \%$ and $5 \%$ of probability, respectively and ${ }^{\text {ns }}$ not significant, by $F$ test. ${ }^{3}$ Coefficient of environmental variation. 
The averages in culture environments ranged from $762 \mathrm{~kg} \mathrm{ha}^{-1}$ (Xambrê, dry season 2012-2013) to $3184 \mathrm{~kg} \mathrm{ha}^{-1}$ (Xambrê, rainy season 2010-2011), with a difference of $2,422 \mathrm{~kg} \mathrm{ha}^{-1}$ between the environments with higher and lower productivity (Table 3 ). This amplitude variation is due in part to the cultivation environment that affected plant development. It is known that adverse environmental conditions such as temperature, water availability and sunlight affect the growth of the plant in different ways, depending on the stage of development that it is (Duarte et al., 2013, Silveira et al., 2013 Fachin et al., 2014). The estimated environmental variation coefficients (CV) ranged from 9 to $25 \%$, showing good experimental precision (Table 2 ).

Table 3 - Grain yield $\left(\mathrm{kg} \mathrm{ha}^{-1}\right)$ of peanut cultivars evaluated in Irati, Londrina, Paranavaí, Santa Tereza do Oeste (S. T. Oeste) and Xambrê in rainy (Ra) and dry (Dry) seasons of 2010-2011, 2011-2012 and 2012-2013.

\begin{tabular}{|c|c|c|c|c|c|c|}
\hline Cultivar & Irati & Londrina & $\begin{array}{c}\text { Paranavaí } \\
\text { Ra 2010-2011 }\end{array}$ & S. T. Oeste & Xambrê & $\begin{array}{c}\text { Irati } \\
\text { Ra 2011-2012 }\end{array}$ \\
\hline IAC Tatu ST & $1,869 \mathrm{a}$ & $2,742 \mathrm{a}$ & $2,323 \mathrm{~b}$ & $2,121 \mathrm{~d}$ & $2,925, a$ & $1,062 \mathrm{~b}$ \\
\hline Runner IAC 886 & $1,540 \mathrm{~b}$ & $2,732 \mathrm{a}$ & $1,577 \mathrm{c}$ & $2,235 \mathrm{c}$ & $3,372 \mathrm{a}$ & $1,060 \mathrm{~b}$ \\
\hline IAPAR 25 Tição & $1,659 \mathrm{~b}$ & $3,058 \mathrm{a}$ & $3,056 \mathrm{a}$ & $1,825 d$ & $3,495 \mathrm{a}$ & $1,290 \mathrm{a}$ \\
\hline Tégua & $1,049 \mathrm{c}$ & $2,472 \mathrm{~b}$ & $1,654 \mathrm{c}$ & $2,821 \mathrm{~b}$ & $3,104 \mathrm{a}$ & $1,165 \mathrm{~b}$ \\
\hline IAC Poitara & $2,176 \mathrm{a}$ & $2,951 \mathrm{a}$ & $2,439 \mathrm{~b}$ & $2,266 \mathrm{c}$ & $3,260 \mathrm{a}$ & $1,374 \mathrm{a}$ \\
\hline IAC Tatuí & $1,944 \mathrm{a}$ & $2,486 \mathrm{~b}$ & $2,507 \mathrm{~b}$ & $3,476 \mathrm{a}$ & $3,171 \mathrm{a}$ & $1,715 \mathrm{a}$ \\
\hline IAC Tupã & $1,617 b$ & $3,055 \mathrm{a}$ & $2,702 \mathrm{a}$ & $3,205 a$ & $3,252 \mathrm{a}$ & $957 \mathrm{~b}$ \\
\hline IAC Oirã & $1,882 \mathrm{a}$ & $2,739 \mathrm{a}$ & $2,640 \mathrm{a}$ & $2,346 \mathrm{c}$ & $3,087 \mathrm{a}$ & $1,090 \mathrm{~b}$ \\
\hline IAC Caiapó & $897 \mathrm{c}$ & $2,529 \mathrm{~b}$ & $1,868 \mathrm{c}$ & $1,986 \mathrm{~d}$ & $3,051 \mathrm{a}$ & $758 \mathrm{~b}$ \\
\hline BRS 151-L7 & $1,741 \mathrm{~b}$ & $2,375 \mathrm{~b}$ & $2,455 b$ & $2,466 \mathrm{c}$ & $3,082 \mathrm{a}$ & $1,477 \mathrm{a}$ \\
\hline BRS Havana & $1,468 \mathrm{~b}$ & $2,514 \mathrm{~b}$ & $2,451 \mathrm{~b}$ & $3,381 \mathrm{a}$ & $3,147 \mathrm{a}$ & $1,350 \mathrm{a}$ \\
\hline BR 01 & $1,058 \mathrm{c}$ & $2,935 \mathrm{a}$ & $2,798 \mathrm{a}$ & $2,443 \mathrm{c}$ & $3,263 \mathrm{a}$ & $1,570 \mathrm{a}$ \\
\hline General Mean & 1,574 & 2,715 & 2,372 & 2,547 & 3,184 & 1,238 \\
\hline Cultivar & Londrina & Paranavaí & Xambrê & Londrina & Paranavaí & Xambrê \\
\hline Gultival & & Ra 2011-201 & --- & & a 2012-201 & \\
\hline IAC Tatu ST & $2,267 \mathrm{c}$ & $660 \mathrm{~b}$ & $552 \mathrm{c}$ & $2,481 \mathrm{a}$ & $2,450 a$ & $1,613 \mathrm{~b}$ \\
\hline Runner IAC 886 & $3,270 \mathrm{~b}$ & $1,396 \mathrm{a}$ & $1,280 \mathrm{~b}$ & $2,323 a$ & $2,024 \mathrm{~b}$ & $1,706 \mathrm{~b}$ \\
\hline IAPAR 25 Tição & $2,517 \mathrm{c}$ & $1,085 \mathrm{a}$ & $642 \mathrm{c}$ & $2,577 \mathrm{a}$ & $2,618 a$ & $1,613 \mathrm{~b}$ \\
\hline Tégua & $3,658 \mathrm{a}$ & $1,129 \mathrm{a}$ & $1,848 \mathrm{a}$ & $2,382 \mathrm{a}$ & $2,350 \mathrm{a}$ & $2,212 \mathrm{a}$ \\
\hline IAC Poitara & $1,866 \mathrm{~d}$ & $985 \mathrm{~b}$ & $642 \mathrm{c}$ & $1,955 \mathrm{~b}$ & $2,037 \mathrm{~b}$ & $1,028 \mathrm{c}$ \\
\hline IAC Tatuí & $1,900 \mathrm{~d}$ & $656 \mathrm{~b}$ & $481 c$ & $2,239 a$ & $2,090 \mathrm{~b}$ & $933 \mathrm{c}$ \\
\hline IAC Tupã & $1,708 \mathrm{~d}$ & $804 \mathrm{~b}$ & $74 \mathrm{c}$ & $2,507 \mathrm{a}$ & $2,857 \mathrm{a}$ & $2,038 \mathrm{a}$ \\
\hline IAC Oirã & $1,865 d$ & $904 \mathrm{~b}$ & $629 c$ & $2,484 \mathrm{a}$ & $2,449 a$ & $1,366 \mathrm{c}$ \\
\hline IAC Caiapó & $2,924 \mathrm{~b}$ & $977 \mathrm{~b}$ & $1,180 \mathrm{~b}$ & $1,967 \mathrm{~b}$ & $2,046 \mathrm{~b}$ & $1,705 \mathrm{~b}$ \\
\hline BRS 151-L7 & $2,179 \mathrm{c}$ & $795 \mathrm{~b}$ & $483 c$ & $1,934 \mathrm{~b}$ & $2,516 \mathrm{a}$ & $1,279 \mathrm{c}$ \\
\hline BRS Havana & $2,582 \mathrm{c}$ & $847 \mathrm{~b}$ & $618 c$ & $2,347 \mathrm{a}$ & $1,996 \mathrm{~b}$ & $1,369 \mathrm{c}$ \\
\hline BR 01 & $2,354 \mathrm{c}$ & $1,344 \mathrm{a}$ & $656 \mathrm{c}$ & $2,101 \mathrm{~b}$ & $1,634 \mathrm{~b}$ & $1,145 \mathrm{c}$ \\
\hline General Mean & 2,424 & 965 & 812 & 2,274 & 2,255 & 1,500 \\
\hline Cultivar & Irati & Paranavaí & S. T. Oeste & Xambrê & --- Dry 2012-2013 --- & Xambrê \\
\hline IAC Tatu ST & $1,349 \mathrm{~b}$ & $1,648 \mathrm{a}$ & $1,740 \mathrm{~b}$ & $1,092 \mathrm{a}$ & $1,326 \mathrm{a}$ & $703 a$ \\
\hline Runner IAC 886 & $911 \mathrm{c}$ & $1,575 \mathrm{a}$ & $1,544 \mathrm{~b}$ & $1,270 \mathrm{a}$ & $1,427 \mathrm{a}$ & $1,007 \mathrm{a}$ \\
\hline IAPAR 25 Tição & $1,278 \mathrm{~b}$ & $1,409 \mathrm{a}$ & $1,842 \mathrm{~b}$ & $1,115 \mathrm{a}$ & $1,025 \mathrm{~b}$ & $501 \mathrm{a}$ \\
\hline Tégua & $1,155 b$ & $1,579 \mathrm{a}$ & $1,479 \mathrm{~b}$ & $1,121 \mathrm{a}$ & $784 \mathrm{~b}$ & $1,024 \mathrm{a}$ \\
\hline IAC Poitara & $2,125 \mathrm{a}$ & $1,757 \mathrm{a}$ & $2,371 \mathrm{a}$ & $1,229 a$ & $1,316 \mathrm{a}$ & $650 \mathrm{a}$ \\
\hline IAC Tatuí & $2,104 \mathrm{a}$ & $1,684 \mathrm{a}$ & $2,076 \mathrm{a}$ & $1,197 \mathrm{a}$ & $1,644 \mathrm{a}$ & $749 a$ \\
\hline IAC Tupã & $1,700 \mathrm{a}$ & $1,789 \mathrm{a}$ & $1,989 a$ & $1,214 a$ & $934 \mathrm{~b}$ & $549 a$ \\
\hline IAC Oirã & $1,896 \mathrm{a}$ & 1,586, a & $2,052 \mathrm{a}$ & $1,137 \mathrm{a}$ & $1,375 a$ & $757 a$ \\
\hline IAC Caiapó & $703 \mathrm{c}$ & $1,676 \mathrm{a}$ & $1,646 \mathrm{~b}$ & $1,383 \mathrm{a}$ & $1,132 b$ & $913 a$ \\
\hline BRS 151-L7 & $1,258 \mathrm{~b}$ & $1,287 \mathrm{a}$ & $1,766 b$ & $1,128 \mathrm{a}$ & $1,587 \mathrm{a}$ & $668 \mathrm{a}$ \\
\hline BRS Havana & $1,194 \mathrm{~b}$ & $1,238 \mathrm{a}$ & $1,851 \mathrm{~b}$ & $1,052 \mathrm{a}$ & $1,891 \mathrm{a}$ & $812 \mathrm{a}$ \\
\hline BR 01 & $1,297 \mathrm{~b}$ & $1,567 \mathrm{a}$ & $1,968 \mathrm{a}$ & $1,039 \mathrm{a}$ & $1,603 \mathrm{a}$ & $816 \mathrm{a}$ \\
\hline General Mean & 1,414 & 1,566 & 1,860 & 1,164 & 1,337 & 762 \\
\hline
\end{tabular}

Values followed by the same lowercase letters vertically are not statistically different from each other. Scott-Knott test at $5 \%$ probability. 
The joint analysis of variance of the 18 environments revealed significant effect at $1 \%$ probability for the cultivar, the environment and the interaction cultivar $x$ environment, which shows different behavior among cultivars, and the inconsistent behavior of them due to environmental variations (Table 4). Changes in the productive performance of peanut lines when grown in different environments were also observed in previous studies in other regions of the country (Oliveira et al., 2006b, Santos et al., 2010; 2012a,b). The occurrence of the effect of $\mathrm{G} \times \mathrm{E}$ interaction is predictable, because the crops were carried out during the rainy and dry seasons, and the localities have different edaphoclimatic conditions.

Table 4 - Joint analysis of variance for grain yield $\left(\mathrm{kg} \mathrm{ha}^{-1}\right)$ in 12 peanut cultivars evaluated in 18 environments of Paraná State, Brazil.

\begin{tabular}{|c|c|c|c|}
\hline Sources of Variantion & Degrees of Freedon & Mean Square & ${ }^{1} \mathrm{~F}$ values \\
\hline Block/Environment & 54 & 335,815 & - \\
\hline Block & 3 & 186,474 & - \\
\hline Block $\times$ Environment & 51 & 344,600 & - \\
\hline Cultivar (Cult) & 11 & 325,632 & $3.64^{\star *}$ \\
\hline Environment (Env) & 17 & $23,947,461$ & $71.31^{* *}$ \\
\hline Cult. x Env. & 187 & 492,200 & $5.49^{* *}$ \\
\hline Cult / Env & 198 & 482,947 & $5.39^{\star \star}$ \\
\hline Cult / Env 1 & 11 & 629,466 & $7.02^{\star *}$ \\
\hline Cult / Env 2 & 11 & 232,971 & $2.60^{\star *}$ \\
\hline Cult / Env 3 & 11 & 825,580 & $9.21^{\star *}$ \\
\hline Cult / Env 4 & 11 & $1,205,962$ & $13.46^{* *}$ \\
\hline Cult / Env 5 & 11 & 95,134 & $1.06^{\mathrm{ns}}$ \\
\hline Cult / Env 6 & 11 & 301,238 & $3.36^{\star *}$ \\
\hline Cult / Env 7 & 11 & $1,463,249$ & $16.33^{\star *}$ \\
\hline Cult / Env 8 & 11 & 229,980 & 2.56 ** \\
\hline Cult / Env 9 & 11 & 680,747 & 7.59 ** \\
\hline Cult / Env 10 & 11 & 216,257 & $2.41^{* *}$ \\
\hline Cult / Env 11 & 11 & 462,366 & $5.16^{\star *}$ \\
\hline Cult / Env 12 & 11 & 603,725 & $6.73^{\star *}$ \\
\hline Cult / Env 13 & 11 & 811,263 & $9.05^{\star *}$ \\
\hline Cult / Env 14 & 11 & 119,867 & $1.33^{\text {ns }}$ \\
\hline Cult / Env 15 & 11 & 249,768 & $2.78^{\star \star}$ \\
\hline Cult / Env 16 & 11 & 38,873 & $0.43^{\text {ns }}$ \\
\hline Cult / Env 17 & 11 & 419,122 & $4.67^{* *}$ \\
\hline Cult / Env 18 & 11 & 107.476 & $1.19^{\text {ns }}$ \\
\hline Env / Cult & 204 & $2,446,805$ & $27.31^{* *}$ \\
\hline Env / Cult 1 & 17 & $2,143,704$ & 23.92 ** \\
\hline Env / Cult 2 & 17 & $2,135,898$ & $23.84^{* *}$ \\
\hline Env / Cult 3 & 17 & $3,098,594$ & $34.58^{* *}$ \\
\hline Env / Cult 4 & 17 & $2,715,987$ & $30.31^{* *}$ \\
\hline Env / Cult 5 & 17 & $2,213,726$ & $24.71^{* *}$ \\
\hline Env / Cult 6 & 17 & $2,688,712$ & $30.01^{* *}$ \\
\hline Env / Cult 7 & 17 & $3,207,109$ & $35.79^{\star *}$ \\
\hline Env / Cult 8 & 17 & $2,149,056$ & $23.98^{* *}$ \\
\hline Env / Cult 9 & 17 & $2,020,851$ & $22.55^{\star *}$ \\
\hline Env / Cult 10 & 17 & $2,064,769$ & $23.04^{* *}$ \\
\hline Env / Cult 11 & 17 & $2,641,412$ & $29.48^{\star \star}$ \\
\hline Env / Cult 12 & 17 & $2,281,845$ & $25.47^{\star \star}$ \\
\hline Residue & 594 & 89,584 & - \\
\hline Total & 863 & - & - \\
\hline Mean $\left(\mathrm{kg} \mathrm{ha}^{-1}\right)$ & 1,776 & - & - \\
\hline CV (\%) & 16.85 & - & - \\
\hline
\end{tabular}

The joint analysis of variance of experiments does not provide detailed information of the genotypes with respect to environmental variations. In this context, adaptability and phenotypic stability studies are required to identify genotypes with predictable performance in diverse environments. The methodology of Eberhart \& Russell (1966) uses the estimates of the regression coefficients $\left(\beta_{1 i}\right)$ and regression deviations $\left(\sigma_{d}{ }^{2}\right)$ for obtaining the parameters of adaptability and stability, respectively. The 
adaptability of a genotype refers to its ability to advantageously utilize the environmental stimuli. The cultivars that showed wide adaptation $\left(\beta_{1 i}=1\right)$ were IAC Tatu ST, Tégua, IAC Poitara, IAC Tatui, IAC Oirã, BRS 151-L7, BRS Havana and BR01, indicating satisfactory response to environmental improvements and ability to maintain their income on adverse conditions. The cultivars IAPAR 25 Tição and IAC Tupã had specific adaptation to favorable environments $\left(\beta_{1 i}>1\right)$, these cultivars respond satisfactorily to improvements in environmental conditions. The cultivars Runner IAC 886 and IAC Caiapó had specific adaptation to harsh environments $\left(\beta_{1 i}<1\right)$, being indicated for environments where it is used low technological content or with occurrence of adverse edaphoclimatic conditions (Table 5).

Table 5 - Estimate parameters of adaptability and phenotypic stability for grain yield of 12 peanut cultivars evaluated in 18 environments in the Paraná State, Brazil.

\begin{tabular}{lcccc}
\hline Cultivar & $\begin{array}{c}{ }^{1} \text { Mean } \\
\left(\mathrm{kg} \mathrm{ha}^{-1}\right)\end{array}$ & ${ }^{2} \beta_{1 i}$ & ${ }^{3} \sigma_{d^{2}}$ & $\begin{array}{c}{ }^{4} R^{2} \\
(\%)\end{array}$ \\
\hline IAC Tatu ST & 1,717 & $1.00^{\mathrm{ns}}$ & $16,455.5^{*}$ & 93.1 \\
Runner IAC 886 & 1,791 & $0.89^{*}$ & $124,096.3^{* *}$ & 74.1 \\
IAPAR 25 Tição & 1,811 & $1.17^{* *}$ & $66,659.4^{* *}$ & 89.1 \\
Tégua & 1,832 & $0.90^{\mathrm{ns}}$ & $261,912.8^{* *}$ & 60.5 \\
IAC Poitara & 1,801 & $0.93^{\mathrm{ns}}$ & $103,154.9^{* *}$ & 78.6 \\
IAC Tatuí & 1,836 & $1.01^{\mathrm{ns}}$ & $145,878.6^{* *}$ & 76.4 \\
IAC Tupã & 1,867 & $1.17^{* *}$ & $98,912.7^{* *}$ & 85.7 \\
IAC Oirã & 1,793 & $0.98^{\mathrm{ns}}$ & $37,066.1^{* *}$ & 89.5 \\
IAC Caiapó & 1,629 & $0.87^{*}$ & $105,450.1^{* *}$ & 76.1 \\
BRS 151-L7 & 1,693 & $0.97^{\mathrm{ns}}$ & $21,951.0^{*}$ & 91.9 \\
BRS Havana & 1,783 & $1.07^{\mathrm{ns}}$ & $62,443.3^{* *}$ & 87.9 \\
BR 01 & 1,754 & $0.98^{\mathrm{ns}}$ & $67,897.2^{* *}$ & 85.1 \\
\hline
\end{tabular}

Tean grain yield. ${ }^{1}$ Regression coefficient ${ }^{* *}$, ${ }^{*}$ statistically different from 1 , by the $t$ test, at $1 \%$ and $5 \%$ probability, respectively. ${ }^{3}$ Regression deviation, ${ }^{* *}$, * statistically different from zero, by the $\mathrm{F}$ test, at $1 \%$ and $5 \%$ probability, respectively. ${ }^{4}$ Determination coefficient.

One way to minimize the effect of $G \times E$ interaction is through the recommendation of high phenotypic stability cultivars for the desired trait. However, cultivars showed low predictability of behavior with regression deviation statistically different from zero $\left(\sigma^{2} \neq 0\right)$ by the $F$ test (Cruz \& Regazzi, 1997) (Table 5). Among the cultivars studied, 58.3\% had coefficient of determination $\left(\mathrm{R}^{2}\right)$ above $80 \%$, showing linearity of response to the evaluated environments.

It is noteworthy that the adaptability and phenotypic stability are parameters related to the set of genotypes and environments studied, therefore, the non-coincidence of the performance of some genotypes evaluated in other environments, not used in this study, is admissible. The assessment carried out in the country's Northeast region, with erect peanut cultivars, showed that cultivars BR1, BRS Havana, BRS 151-L7 and IAC Tatu showed broad adaptation, high stability of production and high grain yield, except for IAC Tatu, that was inserted into the group with lower grain yield (Gomes et al., 2007). These results are partially in agreement with those obtained in this study, since these cultivars also showed broad adaptation to 18 evaluated environments in Paraná State, but did not show behavioral stability.

Environmental indices $\left(\mathrm{l}_{\mathrm{j}}\right)$ calculated are shown in Table 6. It is observed that the values given by the indices are indicative of environmental quality (Cruz \& Regazzi, 1997). $\mathrm{I}_{\mathrm{j}}$ negative values indicate unfavorable environments, showing growing areas where the technological index used is low or regions with adverse soil and climatic conditions. Negative environmental indices were observed for the environments $1,6,8,9,12$, conducted during the rainy season, and the environments 13,14,16,17 and 18 in the dry season. Positive ratings indicate favorable environmental settings associated with the regions with appropriate climatic and edaphic conditions to the aptitude of the culture or cultivation areas where high production technology is used. Values of positive environmental indices were found to environments 2 , $3,4,5,7,10$ and 11 conducted in the rainy season, and to environment 15 in dry season.

Analyzes of individual variance for oil content showed significance at $1 \%$ probability to cultivate at all locations evaluated in the rainy season 2010-2011 (Table 7). The ratio between the highest and the lowest mean square (Table 7) found for oil content was 1.75, which enabled the joint analysis, because the residual variances can be considered homogeneous (Banzatto \& Kronka, 2006). 
Table 6 - Environmental indices $\left(\mathrm{I}_{\mathrm{j}}\right)$ and average yield of peanut cultivars in 18 environments in Paraná State, Brazil.

\begin{tabular}{|c|c|c|c|c|c|}
\hline Environment & Season & $\begin{array}{c}\text { Agricultural } \\
\text { Year }\end{array}$ & Location & $\begin{array}{c}\text { General mean } \\
\left(\mathrm{kg} \mathrm{ha}^{-1}\right)\end{array}$ & $\begin{array}{l}\text { Index }\left(\mathrm{I}_{j}\right) \\
\left(\mathrm{kg} \mathrm{ha}^{-1}\right)\end{array}$ \\
\hline 1 & \multirow{5}{*}{ Rainy } & \multirow{5}{*}{$2010-2011$} & Irati & 1575 & -201 \\
\hline 2 & & & Londrina & 2716 & 939 \\
\hline 3 & & & Paranavaí & 2372 & 596 \\
\hline 4 & & & Santa Tereza do Oeste & 2548 & 771 \\
\hline 5 & & & Xambrê & 3184 & 1408 \\
\hline 6 & \multirow{4}{*}{ Rainy } & \multirow{4}{*}{$2011-2012$} & Irati & 1239 & -537 \\
\hline 7 & & & Londrina & 2424 & 648 \\
\hline 8 & & & Paranavaí & 965 & -811 \\
\hline 9 & & & Xambrê & 813 & -964 \\
\hline 10 & \multirow{3}{*}{ Rainy } & \multirow{3}{*}{$2012-2013$} & Londrina & 2275 & 499 \\
\hline 11 & & & Paranavaí & 2255 & 479 \\
\hline 12 & & & Xambrê & 1501 & -276 \\
\hline 13 & \multirow{4}{*}{ Dry } & \multirow{4}{*}{$2011-2012$} & Irati & 1414 & -362 \\
\hline 14 & & & Paranavaí & 1566 & -210 \\
\hline 15 & & & Santa Tereza do Oeste & 1860 & 84 \\
\hline 16 & & & Xambrê & 1165 & -611 \\
\hline 17 & \multirow{2}{*}{ Dry } & \multirow{2}{*}{$2012-2013$} & Santa Tereza do Oeste & 1337 & -439 \\
\hline 18 & & & Xambrê & 762 & -1014 \\
\hline
\end{tabular}

Table 7 - Analyzes of individual variances for oil content (\%) in grains of peanut cultivars evaluated in Irati, Londrina and Santa Tereza do Oeste in the rainy season 2010-2011.

\begin{tabular}{ccccccccc}
\hline & \multicolumn{2}{c}{ Test } & & \multicolumn{3}{c}{${ }^{1}$ Mean Square } & ${ }^{3} \mathrm{CV}$ \\
\cline { 1 - 2 } Season & Year & Location & & Block & ${ }^{2}$ Cultivar & Residue & $(\%)$ \\
\hline Rainy & $2010-2011$ & Irati & & 1.637 & $7.576^{* *}$ & 1.375 & 2.503 \\
Rainy & $2010-2011$ & Londrina & & 3.382 & $8.087^{* *}$ & 2.402 & 3.277 \\
Rainy & $2010-2011$ & Santa Tereza do Oeste & & 0.014 & & $4.869^{* *}$ & 1.690 & 2.807
\end{tabular}

'Degrees of freedom: 3 (block); 11 (cultivar); 33 (residue). ${ }^{2} \mathrm{~F}$ test: ${ }^{* \star} ;{ }^{*}$ significative at $1 \%$ and $5 \%$ of probability, respectively. ${ }^{3}$ Coefficient of environmental variation.

The joint analysis of variance showed a significant effect for cultivar and environment at $1 \%$ probability for the oil content (Table 8). Currently it is observed that most peanut varieties have an average oil content on a dry basis of $45-51 \%$ in the grains, it is noted that these values vary depending on the cultivation area and the genetic constitution of the cultivar (Santos et al., 2012b; Wilson et al., 2013). It is verified that the cultivar $x$ environment interaction was also significant, with $5 \%$ probability, indicating a differential behavior of these cultivars depending on the environment. In this work, the estimated coefficient of variation in joint analysis of variance was $2.88 \%$, indicating good experimental precision in the results (Table 8 ).

The average oil content in the grains was approximately $47 \%$ (Table 9), within the average found in peanut cultivars (Campos-Mondragon et al., 2009). The higher oil contents were observed in
BRS 151-L7 (48.4\%), IAC Tatuí (48.2\%), BRS Havana (48.1\%), IAC Poitara (47.3\%), IAC Oirã (47.1\%) and IAC Tupã (47\%). The identification of cultivars with high yield potential of oil is interesting for the production of biodiesel. Peanut oil, along with other vegetable oils, has been studied with promising results to be used as biofuel in diesel engines (Nakagawa \& Rosolem, 2011). In fact, historical records report that peanut oil was one of the first oils used in the diesel engine in the first decades of the twentieth century (Silva \& Freitas, 2008). The IAC Tatu ST and IAC Runner 886 cultivars showed the lowest oil content at all sites (Table 8). The oil content in cultivars ranged from $44.2 \%$ (IAC Tatu ST in Santa Tereza do Oeste) to $49.6 \%$ (BRS 151-L7 in Londrina) (Table 8). However, taking into account other species of the genus Arachis, an even higher amplitude variation can be observed, from $41.7 \%$ to $61.3 \%$ oil in the grains (Wang et al., 2010). 
Table 8 - Joint analysis of variance for the oil content (\%) in grains of peanut cultivars evaluated in Irati, Londrina and Santa Tereza do Oeste in the rainy season 2010-2011.

\begin{tabular}{lccc}
\hline Sources of Variantion & Degrees of Freedon & Mean Square & ${ }^{1}$ F values \\
\hline Block/Environment & 9 & 1.678 & - \\
\hline Block & 3 & 0.295 & - \\
Block x Environment & 6 & 2.369 & $7.59^{\star *}$ \\
\hline Cultivar (Cult) & 11 & 13.837 & $6.92^{\star *}$ \\
Environment (Env) & 2 & 11.615 & $1.83^{\star}$ \\
Cult. x Env. & 22 & 3.347 & $3.75^{\star *}$ \\
\hline Cult / Env & 33 & 6.844 & $4.15^{\star *}$ \\
Cult / Env 1 & 11 & 7.576 & $4.43^{\star *}$ \\
Cult / Env b 2 & 11 & 8.087 & $2.67^{\star *}$ \\
Cult / Env 3 & 11 & 4.869 & $2.214^{\star *}$ \\
\hline Env / Cult & 24 & 4.036 & $2.870^{\text {ns }}$ \\
Env / Cult 1 & 2 & 5.231 & $1.457^{\text {ns }}$ \\
Env / Cult 2 & 2 & 2.657 & $3.091^{\text {ns }}$ \\
Env / Cult 3 & 2 & 5.634 & $0.105^{\text {ns }}$ \\
Env / Cult 4 & 2 & 0.193 & $8.112^{\star *}$ \\
Env / Cult 5 & 2 & 14.786 & $0.929^{\text {ns }}$ \\
Env / Cult 6 & 2 & 1.693 & $0.005^{\text {ns }}$ \\
Env / Cult 7 & 2 & 0.009 & $0.761^{\text {ns }}$ \\
Env / Cult 8 & 2 & 1.387 & $2.168^{\text {ns }}$ \\
Env / Cult 9 & 2 & 3.951 & $5.137^{\star *}$ \\
Env / Cult 10 & 2 & 9.363 & $1.567^{\text {ns }}$ \\
Env / Cult 11 & 2 & 2.856 & $0.367^{\text {ns }}$ \\
Env / Cult 12 & 2 & 0.670 & - \\
\hline Residue & 143 & 1.822 & - \\
Total & 2.88 & - & - \\
\hline Mean (\%) & & - & - \\
CV (\%) & 46.81 & - & \\
\hline F test: ** * significant at 1\% and 5\% probability, respectively. & & \\
\hline
\end{tabular}

Table 9 - Oil content (\%) in dry basis in grains of peanut cultivars evaluated in Irati, Londrina and Santa Tereza do Oeste in the rainy season 2010-2011.

\begin{tabular}{|c|c|c|c|c|}
\hline \multirow{2}{*}{ Cultivars } & \multicolumn{3}{|c|}{ Locations } & \multirow{2}{*}{$\begin{array}{c}\text { General } \\
\text { mean } \\
(\%)\end{array}$} \\
\hline & ${ }^{1}$ Irati & ${ }^{1}$ Londrina & ${ }^{1}$ Santa Tereza do Oeste & \\
\hline IAC Tatu ST & $44.7 \mathrm{~B} \mathrm{~b}$ & $46.4 \mathrm{~A} \mathrm{~b}$ & $44.2 \mathrm{~B} \mathrm{~b}$ & $45.1 \mathrm{~b}$ \\
\hline Runner IAC 886 & $44.6 \mathrm{~A} \mathrm{~b}$ & $45.1 \mathrm{~A} \mathrm{~b}$ & $46.2 \mathrm{~A} \mathrm{a}$ & $45.3 \mathrm{~b}$ \\
\hline IAPAR 25 Tição & $46.8 \mathrm{~A} \mathrm{a}$ & $47.0 \mathrm{~A} \mathrm{~b}$ & $44.8 \mathrm{~B} \mathrm{~b}$ & $46.2 \mathrm{~b}$ \\
\hline Tégua & 46.3A b & $46.4 \mathrm{~A} \mathrm{~b}$ & $46.7 \mathrm{~A} \mathrm{a}$ & $46.5 \mathrm{~b}$ \\
\hline IAC Poitara & $47.7 \mathrm{~A} \mathrm{a}$ & $49.0 \mathrm{~A} \mathrm{a}$ & $45.2 \mathrm{~B} \mathrm{~b}$ & $47.3 \mathrm{a}$ \\
\hline IAC Tatuí & $48.5 \mathrm{~A} \mathrm{a}$ & $48.6 \mathrm{~A} \mathrm{a}$ & $47.4 \mathrm{~A} \mathrm{a}$ & $48.2 \mathrm{a}$ \\
\hline IAC Tupã & $47.0 \mathrm{~A} \mathrm{a}$ & $47.1 \mathrm{~A} \mathrm{~b}$ & $47.0 \mathrm{~A} \mathrm{a}$ & $47.0 \mathrm{a}$ \\
\hline IAC Oirã & $47.7 \mathrm{~A} \mathrm{a}$ & 46.7A b & $46.7 \mathrm{~A} a$ & $47.1 \mathrm{a}$ \\
\hline IAC Caiapó & $45.7 \mathrm{~A} \mathrm{~b}$ & $46.4 \mathrm{~A} \mathrm{~b}$ & $47.6 \mathrm{~A} \mathrm{a}$ & $46.6 \mathrm{~b}$ \\
\hline BRS 151-L7 & $48.9 \mathrm{~A} \mathrm{a}$ & $49.6 \mathrm{~A} \mathrm{a}$ & $46.7 \mathrm{~B} \mathrm{a}$ & $48.4 \mathrm{a}$ \\
\hline BRS Havana & $47.9 \mathrm{~A} \mathrm{a}$ & $49.1 \mathrm{~A} \mathrm{a}$ & $47.4 \mathrm{~A} \mathrm{a}$ & $48.1 \mathrm{a}$ \\
\hline BR 01 & $46.5 \mathrm{~A} \mathrm{~b}$ & $46.2 \mathrm{~A} \mathrm{~b}$ & $45.7 \mathrm{~A} \mathrm{~b}$ & $46.1 \mathrm{~b}$ \\
\hline Mean & 46.9 & 47.3 & 46.3 & 46.8 \\
\hline
\end{tabular}

${ }^{\top}$ Values followed by the same capital letters in horizontal and lowercase letters in vertical belong to the same group. Scott-Knott test, $5 \%$ probability. 


\section{Conclusions}

The cultivars showed genetic variability for oil content in grain, highlighting BRS 151-L7, IAC Tatuí, BRS Havana, IAC Poitara, IAC Oirã and IAC Tupã, with the highest average levels of oil.

Regarding grain yield, the Runner IAC 886 and IAC Caiapó cultivars had specific adaptation to harsh environments, while IAPAR 25 Tição and IAC Tupã had it to favorable ones. In terms of stability, IAC Tatu ST was the most predictable and Tégua the least stable, since the estimate of its determination coefficient was the lowest among the tested cultivars.

\section{References}

AOAC - Association of Official Analytical Chemists (1990) Official methods of analysis of the association of official analytical chemistry. AOAC.1005 p.

Banzatto DA, Kronka SN (2006) Experimentação Agrícola. FUNEP. 237p.

Campos-Mondragon MG, Calderón de la Barca AM, Durán-Prado A, Campos-Reyes LC, Oliart-Ros RM, Ortega-García J, Medina-Juárez LA, Ângulo O (2009) Nutritional composition of new peanut (Arachis hypogaea L.) cultivars. Grasas y Aceites 60(2): 161-167. doi:10.3989/gya.075008

CONAB - Companhia Nacional de Abastecimento (2013) Levantamento e estimativa de produção da safra 2012/2013. Disponível em: <http://www.conab.gov.br/OlalaCMS/uploads/arquivos/ 13_08_09_10_43_44

_boletim_portuges_agosto_2013_port.pdf./ >. (Acesso em: 06 set 2013).

Crusciol CAC, Soratto RP (2007) Nutrição e produtividade do amendoim em sucessão ao cultivo de plantas de cobertura no sistema plantio direto. Pesquisa Agropecuária Brasileira 42(11):1553-1560.

Cruz CD, Regazzi AJ (1997) Modelos Biométricos aplicados ao melhoramento genético. UFV. 390p.

Cruz CD (2006) Programa Genes: Biometria. UFV. $382 \mathrm{p}$.

Duarte EAA, Melo Filho PA, Santos RC (2013) Características agronômicas e índice de colheita de diferentes genótipos de amendoim submetidos a estresse hídrico. Revista Brasileira de Engenharia Agrícola e Ambiental 17(8):843-847.

Eberhart SA, Russell WA (1966) Stability parameters for comparing varieties. Crop Science 6(1):36-40.

Fachin GM, Duarte Júnior JB, Glier CAS, Mrozinski, CR, Costa ACT, Guimarães VF (2014) Características agronômicas de seis cultivares de amendoim cultivadas em sistema convencional e de semeadura direta. Revista Brasileira de Engenharia Agrícola e Ambiental 18(2):165-172.
FAO - Food and Agriculture Organization (2013) Disponível em: <http://www.fao.org/>. Acesso em: 12 out 2013.

Gomes LR, Santos RC, Anunciação Filho CJ, Melo Filho PA (2007) Adaptabilidade e estabilidade fenotípica de genótipos de amendoim de porte ereto. Pesquisa Agropecuária Brasileira 42(7):985-989.

Murakami DM, Cruz CD (2004) Proposal of methodologies for environment stratification and analyses of genotype adaptability. Crop Breeding and Applied Biotechnology 4(1):7-11.

Nakagawa J, Rosolem C (2011) O amendoim: tecnologia de produção. FEPAF. 325p.

Oliveira AB, Duarte JB, Chaves LJ, Couto MA (2006a) Environmental and genotypic factors associated with genotype by environment interactions in soybean. Crop Breeding and Applied Biotechnology 6(1):79-86.

Oliveira EJ, Godoy IJ, Moraes ARA, Martins ALM, Pereira JCVNA, Bortoletto N, Kasai FS (2006b) Adaptabilidade e estabilidade de genótipos de amendoim de porte rasteiro. Pesquisa Agropecuária Brasileira 41(8):1253-1260.

Santos RC, Rêgo GM, Silva APG, Vasconcelos JOL, Coutinho JLB, Melo Filho PA (2010) Produtividade de linhagens avançadas de amendoim em condições de sequeiro no Nordeste brasileiro. Revista Brasileira de Engenharia Agrícola e Ambiental 14(6):589-593.

Santos CS, Silva AF, Gondim TMS, Oliveira Júnior JOL, Araújo Neto RB, Sagrilo E, Vasconcelos RA, Melo Filho PA, Silva Filho JLJ (2012a) Stability and adaptability of runner peanut genotypes based on nonlinear regression and $\mathrm{AMMI}$ analysis. Pesquisa Agropecuária Brasileira 47(8):1118-1124.

Santos RC, Freire RMM, Lima LM, Zagonel GF, Costa BJ (2012b) Produtividade de grãos e óleo de genótipos de amendoim para o mercado oleoquímico. Revista Ciência Agronômica 43(1):72-77.

SEAB - Secretaria da Agricultura e do Abastecimento do Paraná / DERAL - Departamento de Economia Rural. (2012). Comparativo de Área, Produção e Produtividade no Paraná nas Safras 10/11 - 11/12. Disponível em: http://www.agricultura.pr.gov.br/modules/qas/uploads/3 221/pss_2011_12.pdf/. Acesso em: 07 jan. 2013.

Silva WCJ, Duarte JB (2006) Métodos estatísticos para estudo de adaptabilidade e estabilidade fenotípica em soja. Pesquisa Agropecuária Brasileira 41(1):23-30.

Silva PRF, Freitas TFS (2008) Biodiesel: o ônus e o bônus de produzir combustível. Ciência Rural 38(3):843-851. 
Silveira PS, Peixoto CP, Ledo CAS, Passos AR, Borges VP, Bloisi LFM (2013) Fenologia e produtividade do amendoim em diferentes épocas de semeadura no recôncavo sul baiano. Bioscience Journal 29(3):553-561.

Wang ML, Barkleya NA, Chinnana M, Stalkera HT, Pittman RN (2010) Oil content and fatty acid composition variability in wild peanut species. Plant Genetic Resources 8(3):232-234.
Wilson JN, Baring MR, Burow MD, Rooney WL, Simpson CE (2013) Generation Means Analysis of Oil Concentration in Peanut. Journal of Crop Improvement 27(1):85-95.

Zhao X, Chen J, Du F (2012) Potential use of peanut by-products in food processing: a review. Journal of food Science and Technology 49(5):521-529. 